\title{
45. SLICKENSIDES IN DEEP SEA CORES NEAR THE JAPAN TRENCH, LEG 57, DEEP SEA DRILLING PROJECT
}

\author{
George W. Moore, U.S. Geological Survey, Menlo Park, California
}

\begin{abstract}
Slickenside-bearing fractures occur below a sub-bottom depth of 132 meters in cores from Deep Sea Drilling Project Site 441, located on the lower trench slope of the Japan Trench. The fractures are considered to be tectonic microfaults because (1) they resemble onshore microfaults, (2) the bedding in the cores is also deformed, and (3) the site lies only $15 \mathrm{~km}$ from an active trench. Most of the slickensided surfaces are broken by a series of steps, with treads and risers; the angle between the treads and the average fracture surface is about $3^{\circ}$. Slickenside steps with similar tread angles that occur in land outcrops, where the sense of displacement can be independently determined, face in the direction of displacement. About 60 per cent of the faults in the cores are reverse faults, indicating that the trench slope strata are being compressed. About 25 per cent, both reverse and normal, have dips of less than $20^{\circ}$. The slickenside-bearing fractures are believed to be caused by thrusting and buckling of the trench slope cover as more highly deformed rocks below the cover and closer to the surface of maximum shear are rotated and consolidated.
\end{abstract}

\section{INTRODUCTION}

The holes drilled during Deep Sea Drilling Project Leg 57 penetrate strata on the landward side of the Japan Trench at a series of sites selected to study differences in the strata that are related to distance from the trench. Sites 438 and 439 lie about $40 \mathrm{~km}$ landward from the top of the trench slope; Site 440 is on a midslope terrace of the Trench slope; and Site 441 lies on the lower part of the trench slope, 15 kilometers from the trench itself (Figure 1). This chapter describes fresh-looking open microfaults at Site 441 and discusses the state of stress of the rocks.

The deformation of the strata at the different sites changes systematically as the trench is approached. The gradual reduction in the shallowest sub-bottom depth at which conspicuous fractures cut the cores (Figure 2) demonstrates the difference in origin of brittle fracturing with respect to tectonic setting. At Site 441, nearest to the trench, in water about 5650 meters deep (Figure 3 ), fractures occur in upper Pliocene rocks at a subbottom depth of only 132 meters. Shear and tectonic consolidation related to underthrusting of the Pacific Plate probably formed the fractures at such shallow depths near the Japan Trench.

The strata drilled at Site 441 are believed to have been deposited on the trench slope (see Site 441 Chapter, Part 1). This interpretation is based on a lack of repeated paleontologic zones, an absence of infaulted material from the oceanic plate, and a uniform stratigraphic sequence down to the upper Miocene. The rock at Site 441 consists of homogeneous hemipelagic claystone and diatomaceous claystone. Bedding is ordinarily indistinct, but rare measurements indicate that the dip is less than $20^{\circ}$ down to about 400 meters, as much as $35^{\circ}$ between 400 and 600 meters, and possibly greater than $35^{\circ}$ below that.

Hole deflection surveys were made approximately every 100 meters in the three holes drilled at Site 441 . Deflection from the vertical does not exceed $3.6^{\circ}$ except for one survey in Hole 441B at 668 meters, which shows a deflection of more than $6.0^{\circ}$. Fault dip and slip vector measurements from that part of Hole 441B have been excluded from the analysis of this paper.

\section{TYPES OF SLICKENSIDES}

Slickensides mark many subplanar slightly polished fault surfaces in the claystone and diatomaceous claystone of Site 441. The cores break apart along the fault surfaces, which, in some cases, cut across other fractures that are healed. The slickensides consist of somewhat irregular shallow grooves on an average of $8 \mathrm{~mm}$ apart (Figure 4).

On sawed core halves held vertically, using as a vertical reference the intersection between the saw cut and the cylindrical core surface, a protractor measured the dips of the slickensided surfaces with an average precision of about $5^{\circ}$. Slickenside rakes, also determined with a precision of about $5^{\circ}$, consist of the acute angle, measured in the plane of the slickensided surface, between the grooves and the horizontal (Figure 5). Clockwise and counterclockwise rakes designate the apparent rotation of the grooves from the horizontal on the footwall. 


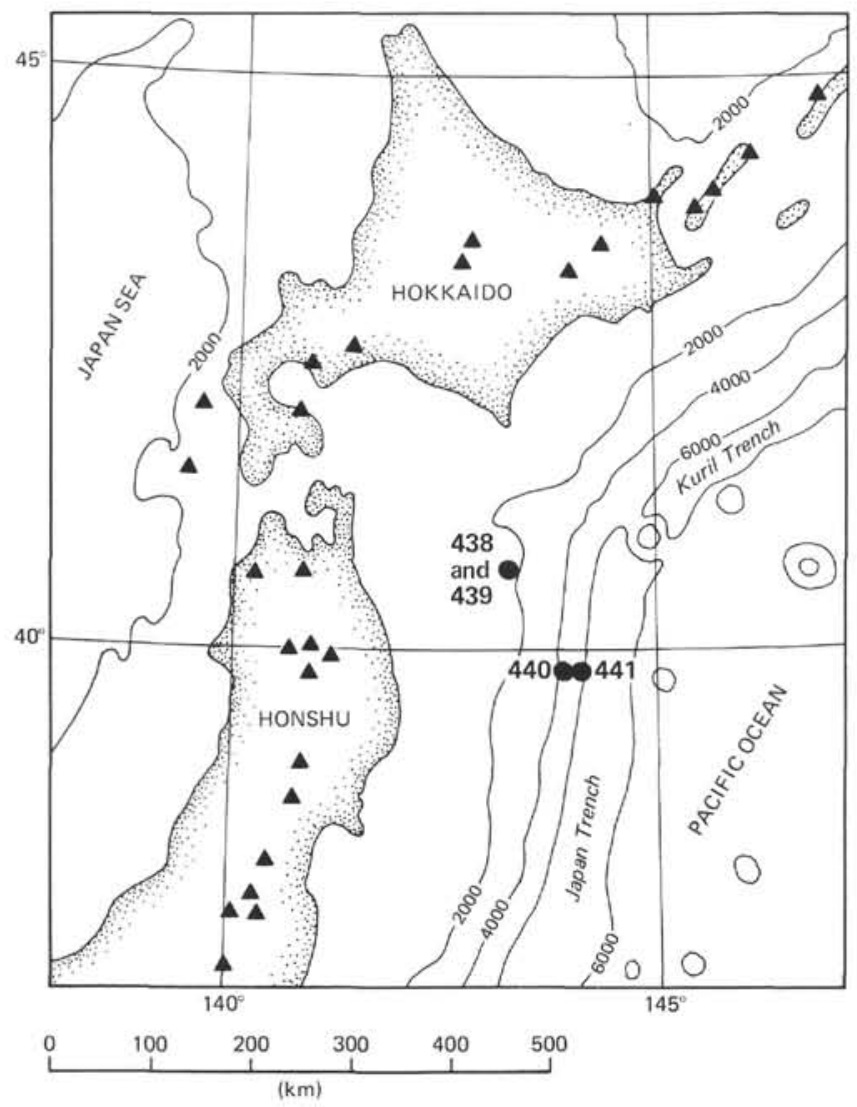

Figure 1. Location of Leg 57 Deep Sea Drilling Project sites in relation to the Japan Trench. Triangles mark active volcanoes; depth contours are in meters.
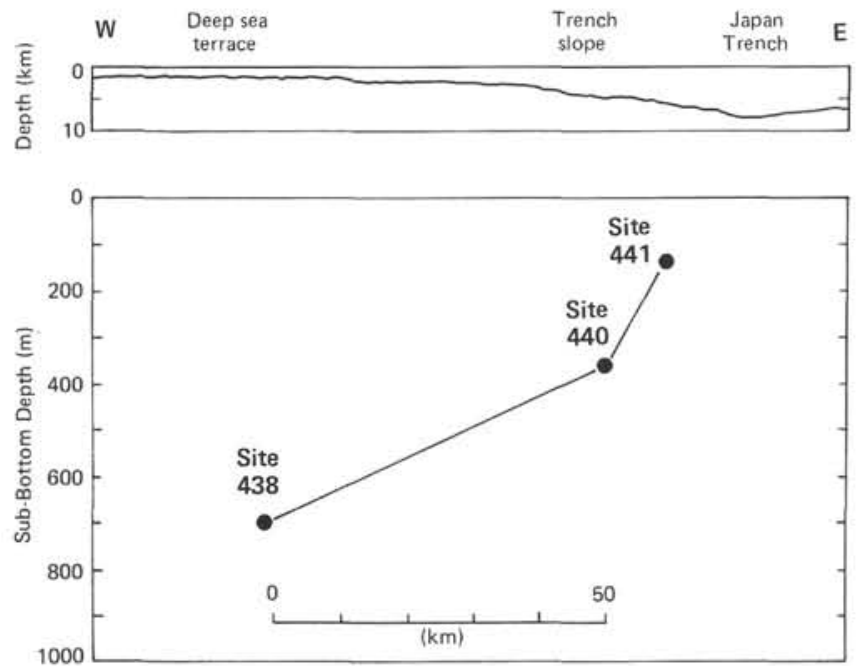

Figure 2. Sub-bottom depth at which conspicuous brittle fractures occur in cores near the Japan Trench.

The slickensided surfaces in the cores from Site 441 contain steps about $10 \mathrm{~mm}$ long on which risers about $0.5 \mathrm{~mm}$ high separate treads that usually lie at an angle of about $3^{\circ}$ to the average for the fault surfaces (Figure 6). Figure 7 shows the five types of steps seen in the cores, which probably also represent the range of types that would be expected in similar rocks elsewhere. In Types A, B, and C the edge between the tread and riser is smoothly rounded, so that the riser constitutes a continuation of the slip surface that follows the tread. In Types D and $E$ the risers are steep fractures between en echelon slickensided treads. These steep fractures probably formed when the cores broke apart after recovery to expose the slickensides and are not directly related to the faulting.

In slickenside Type A, which constitutes 50 per cent of the slickensides in these cores, rounded risers slope at about $15^{\circ}$ to the average fault surface (Figure 7). Type B is less smoothed by slip than Type A, and in Type B the risers follow $15^{\circ}$ en echelon fractures that extend below the treads. Fractures that bear a similar $15^{\circ}$ angular relation to the main shear direction also occur in slickenside Type $\mathrm{E}$ and possibly in Type $\mathrm{C}$. These $15^{\circ}$ fractures are probably riedel fractures, the first fractures that form when laboratory materials are deformed by shear (Riedel, 1929).

The slickensided surfaces are fresh and nonmineralized and do not contain vein material in tensional gashes or at dilational curves that might have directional significance (Proust et al., 1974). Also, because the rocks are fine grained, harder particles on the shear surfaces generally have not engraved useful direction-indicating prod marks (Tjia, 1972). Therefore, the configuration of the slickenside steps has been used to separate the steps into two main groups: (1) steps on which the angle between presumed riedel fracture treads and the average fracture surface is $15^{\circ}$ and which Paterson (1958) shows in laboratory studies to face opposite to the direction of fault movement and (2) steps on which the angle is $3^{\circ}$ and which Proust and others (1974) show from outcrop studies to face in the direction of movement.

Riedel fractures bear an en echelon relationship to the main shear direction (Figure 8), and extensive further slip cannot occur without new fracturing of the material between the riedel fractures. They are probably tension fractures triggered by incipient shear along a diagonal between the greatest and least stress directions. Riedel fractures form because the material is weaker in tension than in shear, and they relieve initial strain by stepwise slip along the en echelon fracture segments and by rotation of the material between them.

Both in natural fault zones (at scales that range from kilometer size to micrometer size) and in fault zones in laboratory experiments, the riedel fractures, $15^{\circ}$ from the main fault surface, commonly become linked together into throughgoing faults by connecting fractures that are inclined at about $3^{\circ}$ from the main fault surface and $18^{\circ}$ from the riedel fractures (Tchalenko, 1970). The origin of these connecting fractures has been a matter of controversy. I think they are formed in the same way as inferred for the riedel fractures-that is, by tension triggered along diagonals related to a secondary shear direction that, owing to disruption of the stress field by the riedel fractures, is reoriented by $18^{\circ}$ from the principal shear direction.

Numerous field studies using independent direction indicators have shown that when connecting fractures 


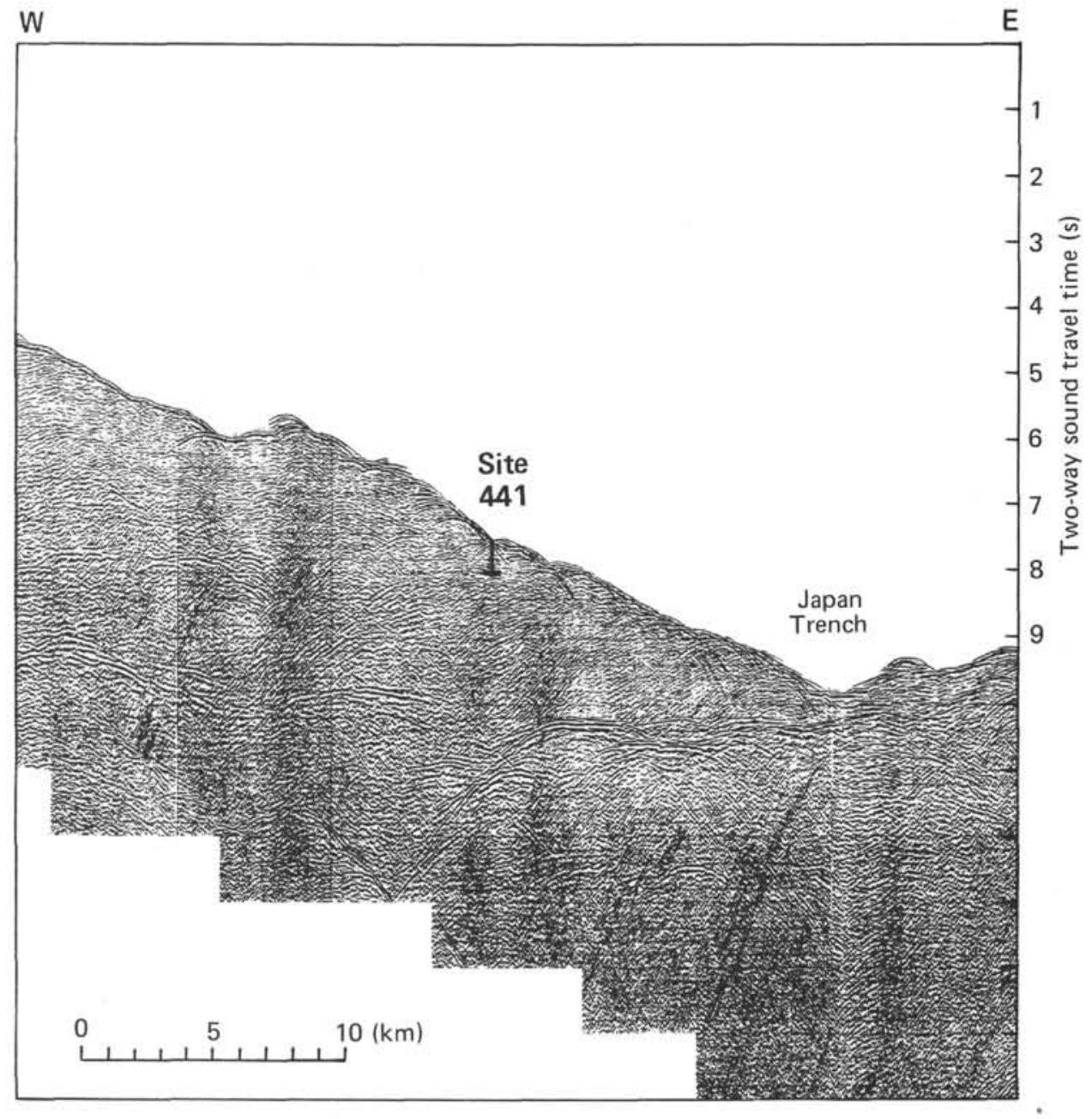

Figure 3. Sub-bottom reflectors below the trench slope of the Japan Trench in the area of Site 441.

inclined at about $3^{\circ}$ constitute the treads of slickenside steps, the slickensides are congruent-that is, the risers face in the direction of fault movement (Norris and Barron, 1969; Tjia, 1972; Proust et al., 1974). In the present study, this evidence has been used to infer that slickenside Types A, B, C, and D are congruent. Type E, however, on which the treads are inclined at $15^{\circ}$ to the main fault surface, is considered to be incongruent, because the risers seem to oppose fault movement (Figure 9). In the Site 441 cores, this interpretation is supported by the fact that all fault surfaces known to bear Type E slickenside steps also contain congruent steps, usually of Type A.

On some faults, the slickenside types are intergradational. Only one generation of slickensided open faults has been recognized in the cores. Local factors presumably dictate which of the fracture orientations will constitute various parts of a slickensided surface, and the observed slip directions probably represent the last movement.

\section{ORIGIN OF THE SLICKENSIDES}

The properties of the slickensided microfaults at Deep Sea Drilling Project Site 441 on the trench slope of the Japan Trench are plotted in Figure 10. The slickensided surfaces commonly occur in parallel sets. The faults do not constitute a penetrative fracture cleavage, as identified at Site 298 above the Shikoku subduction zone off southern Japan (Moore and Karig, 1976), because conjugate fault pairs in the cores intersect at approximately $90^{\circ}$ and hence follow different fabric orientations. Slip vectors for fault pairs in coherent pieces of core are given in Table 1. Although the absolute rotational orientation of each core piece as a whole is unknown, the relative movements along the pairs of slip vectors indicate how the blocks bounded by the microfaults have moved with respect to their neighbors.

The fracture cleavage at Site 298 in the Shikoku area is cut by slickensided faults similar to those at Site 441 and probably of the same origin. Karig, Ingle, et al. (1975, p. 322) infer that the slickensided microfaults at Site 298 were induced by the drilling process, on the basis of similar features so interpreted in onshore drill holes. Kidd (1978) has reviewed the natural and drilling effect origins of microfaults found previously by the DSDP in areas of tectonic instability and concludes that although such microfaults in the past have usually been considered drilling artifacts, "more careful investigation 


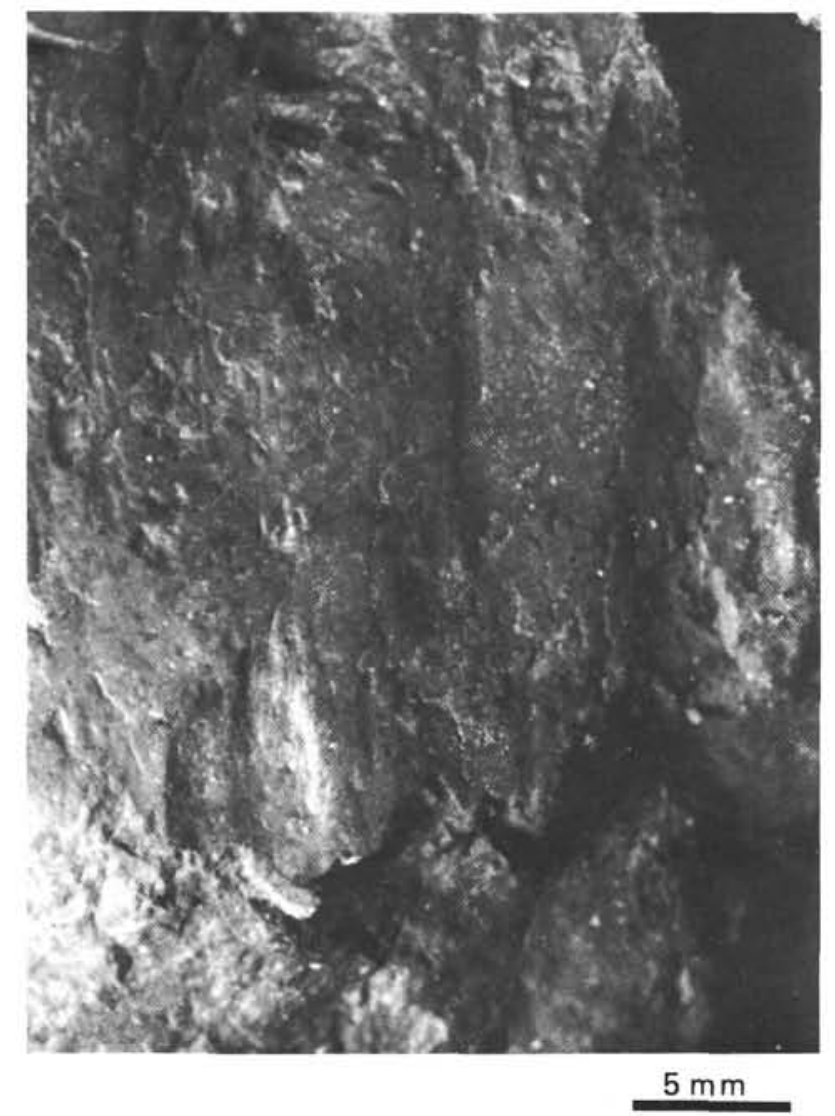

Figure 4. Typical slickenside grooves in core from the trench slope of the Japan Trench on a fault cutting upper Miocene claystone breccia. The overlying block moved downward with respect to the photographed block (oriented arbitrarily), producing slickenside Type A of this chapter. Specimen 441A-11-1, $38 \mathrm{~cm}$ (sub-bottom depth $586 \mathrm{~m}$ ).

for possible original microtectonic features is warranted (p. 1147)."

Slickensided fractures in oriented cores of Pliocene rock from the Ventura Basin in California resemble those of the present study and show a systematic relationship to faulting, as mapped at the surface and in numerous oil wells (Friedman, 1969). On the basis of the evidence from the Ventura Basin, Friedman defined the likelihood that core fractures are natural under three headings: Unequivocal, Very Probable, and Probable. Unequivocal natural fractures are those associated with gouge or vein material, and in his definition: "Very Probable natural fractures are those with slickenside surfaces (p. 369)." Unlike the fractures at Site 441, fracture surfaces known to be induced by drilling are conspicuously curved, the hackle-mark steps on the surfaces change in height across the cores, and the hackle marks are noticeably divergent (Kulander et al., 1977).

The successively greater dips measured at increasing sub-bottom depth in the trench slope strata at Site 441 record a continuing deformation that is compatible with a natural origin for the slickensided fractures. The shipboard scientists included many measurements of these

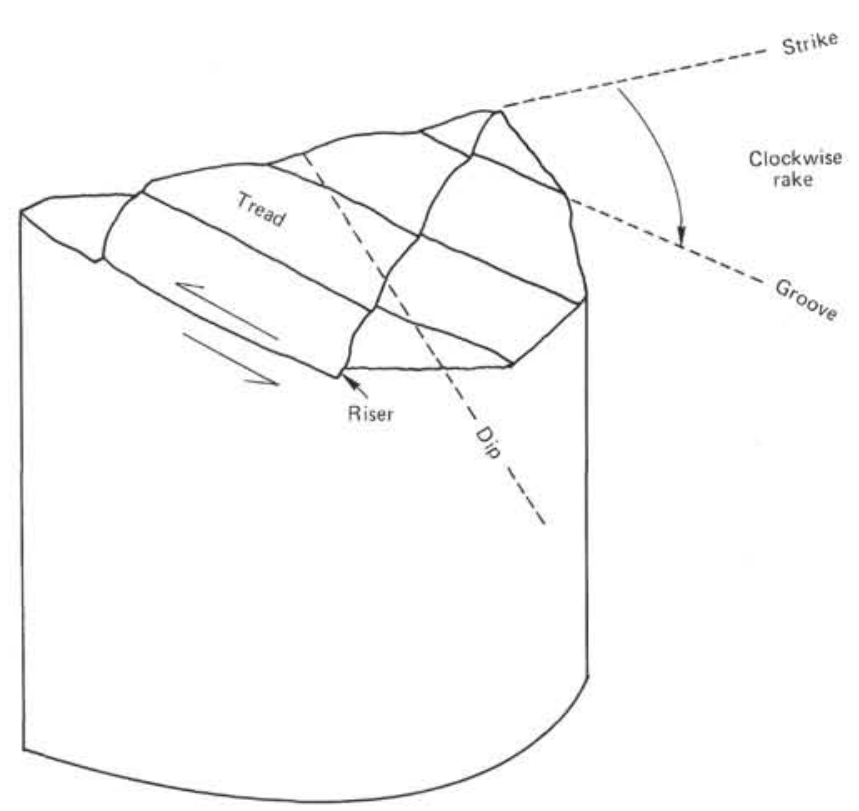

Figure 5. Slickenside nomenclature showing the relationship in a half core between step risers and displacement on a low-angle clockwise reverse fault.

faults in the initial core description for Site 441, whereas such fractures are rarely noted at deep ocean sites far from active trenches.

The occurrence of this type of fresh fracture at both the Shikoku and Japan subduction zones suggests a natural association with plate convergence. We might consider that a high differential pressure at the relatively great water depth near the Japan Trench caused the core to intrude the bit and thus produce the fractures artificially. But the depth of 4628 meters at Site 298 at the Shikoku subduction zone is shallower than many DSDP sites that lack conspicuous fractures.

Hypothetical drilling-induced fractures caused by tectonic overconsolidation at subduction zones might be difficult to distinguish from fractures that were there before the drilling. In either case, however, natural rock deformation is involved, and a comparison with the similar rocks of the Ventura basin suggests that the slickensided fractures at Site 441 do indeed predate the drilling. If so, systematic patterns shown by the slickenside slip vectors might be used to help infer the local strain conditions in strata relatively near the sea floor on the trench slope of the Japan Trench.

\section{CONCLUSIONS}

Slickenside slip vectors are useful in nonoriented cores because they define the relative amounts of vertical and horizontal fault movement and because they indicate whether horizontal tension (normal faults) or horizontal compression (reverse faults) predominates. The principal properties of the 30 microfaults studied at Site 441 are as follows: (1) 60 per cent are reverse faults; (2) 70 per cent are steeper than $45^{\circ}$; (3) 70 per cent are predominantly dip-slip; (4) 90 per cent of the 30 per cent that are mainly strike-slip have a reverse compo- 


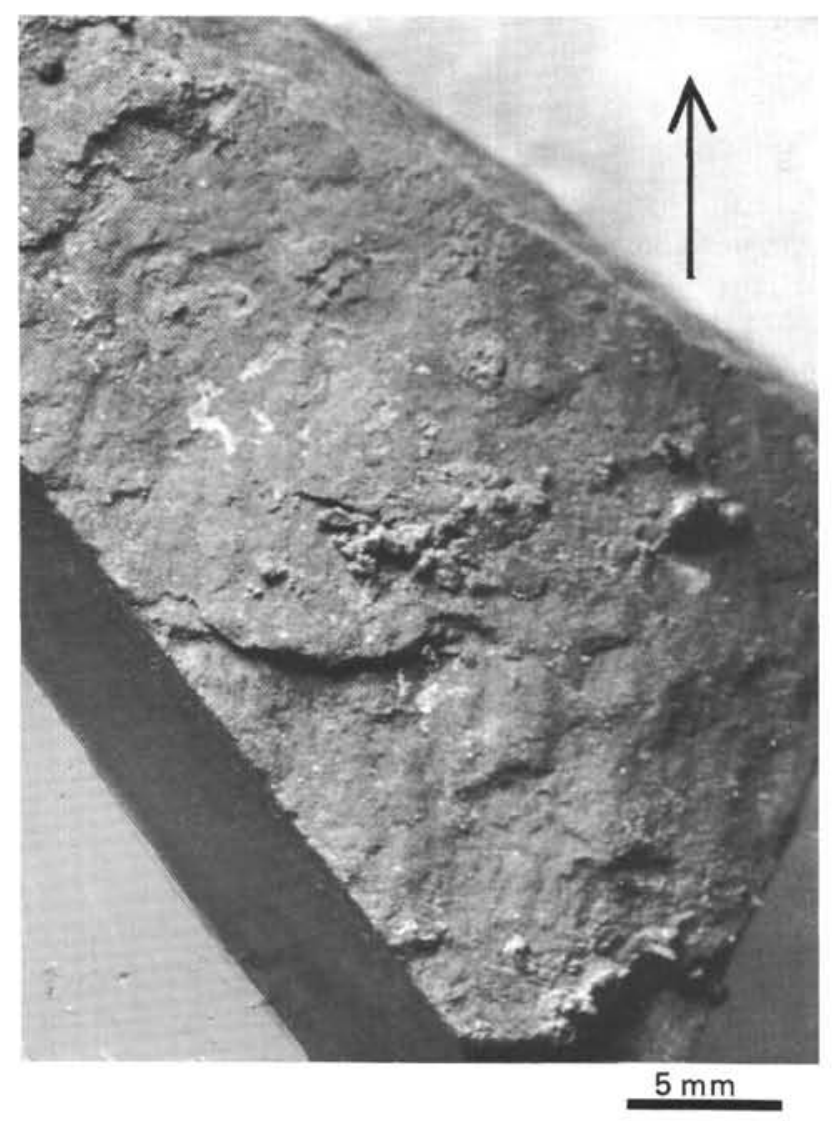

Figure 6. Typical slickenside steps (Type D of this chapter), in which this block moved in the direction of the arrow with respect to the overlying removed block. The step risers are oriented so as to face the movement of the other block and hence are considered congruent. The step treads lie at an angle of about $3^{\circ}$ to the average fault surface. Specimen $441-\mathrm{HI}-4,117 \mathrm{~cm}(258-329 \mathrm{~m})$, Pliocene diatomaceous claystone.

nent; (5) 90 per cent of the normal faults have a clockwise rake.

Seven of the slickensided faults have dips of less than $20^{\circ}$. All of these have rakes that are clockwise. This means that the relative transport of the footwalls is consistently deflected to the left and suggests that they might all belong to a single fault set.

This group of low-angle faults could have formed by sliding, by thrusting, or by buckling. Because evidence for submarine slides is not obvious on the reflection profile (Figure 3 ), thrusting and buckling are probably more important than sliding in generating the faults (Figure 11).

The sea floor on the lower trench slope is disrupted in places, as shown by its rough surface on the reflection profile. The moderate dips measured near the bottom of the holes show that the drilled rocks have been deformed by the subduction that has gone on below. An even more disturbed zone shown on the reflection profile below the drilled section suggests that the lowest
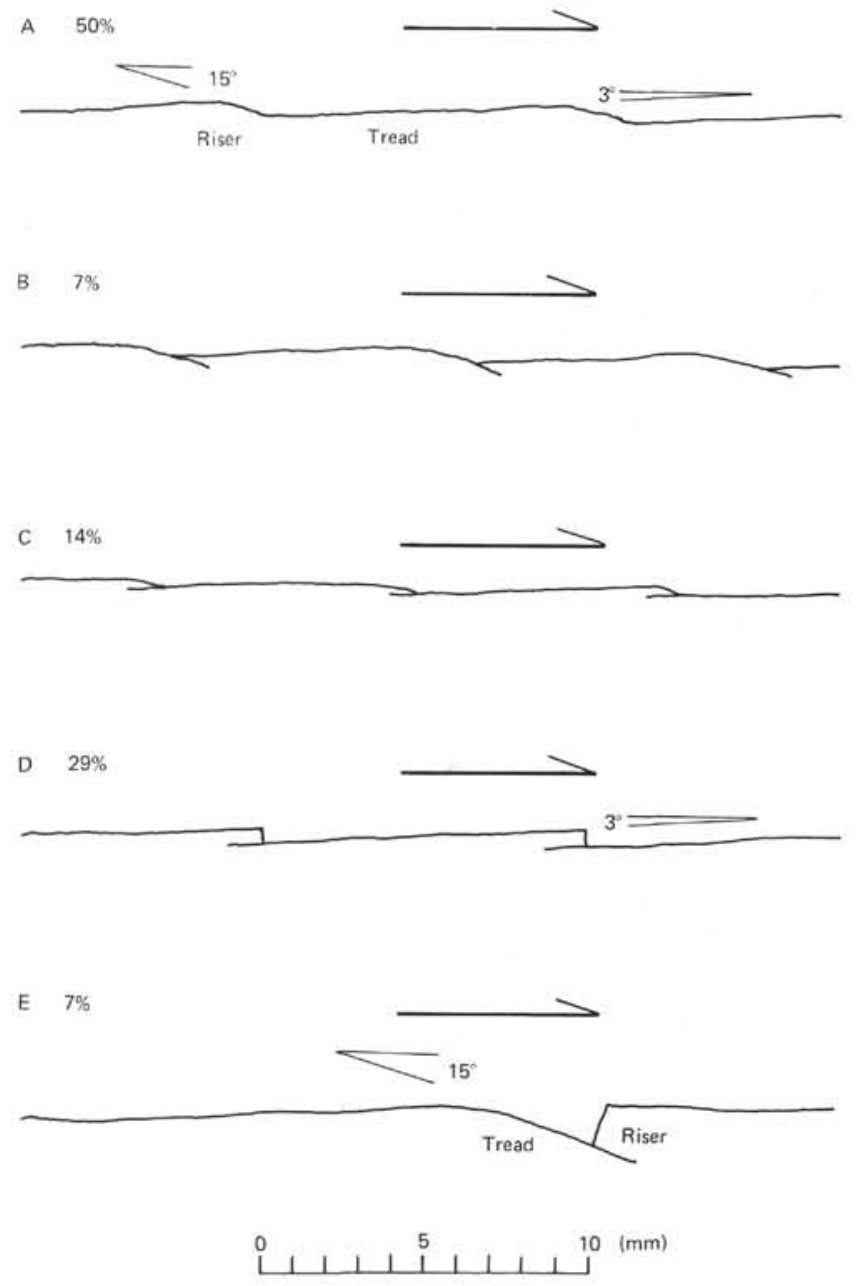

Figure 7. Types of slickenside steps in claystone at Site 441 , showing the relative movement of the overlying blocks, typical angles between the average fault surface and various step surfaces, and the relative abundance of each slickenside type. The percentage totals more than 100 because Type $\mathrm{E}$, in which the riser seems to oppose fault movement, always occurs in conjunction with one of the other types.

cores are close to greatly deformed rocks. The greatly deformed rocks probably undergo continuous consolidation and rotation as subduction proceeds below and as new trench slope sediment is deposited. These processes shorten the overlying younger deposits, as the Pacific Plate converges against the Japanese Islands, and cause compression, buckling, and shearing. As a consequence the slickensided faults develop where the strata have become coherent enough to sustain brittle fracture.

\section{ACKNOWLEDGMENTS}

I have benefited from numerous discussions on this topic with Roland von Huene, Jean-Paul Cadet, Kenneth A. Pisciotto, and especially Michael Arthur. The final draft of the manuscript was reviewed by Hugh McLean and J. Casey Moore. 


\section{REFERENCES}

Friedman, M., 1969. Structural analysis of fractures in cores from Saticoy Field, Ventura County, California. Bull. Am. Assoc. Petrol. Geol., 53, 367-389.

Karig, D. E., Ingle, J. C. Jr., et al. 1975. Site 298. In Karig, D. E., Ingle, J. C., Jr., et al., Init. Repts. DSDP, Washington (U.S. Govt. Printing Office), 317-350.

Kidd, R. B., 1978. Core-discing and other drilling effects in DSDP Leg 42A Mediterranean sediment cores. In Hsü, K. J., Montadert, L., et al., Init. Repts. DSDP, 42, Pt. 1: Washington (U.S. Govt. Printing Office), 1143-1149.

Kulander, B. R., Dean, S. L., and Barton, C. C., 1977. Fractographic logging for determination of pre-core and coreinduced fractures-Nicholas Coombs No. 7239 well, Hazard, Kentucky. Energy Research and Development Administration Report No. MERC/CR-77/3.

Moore, J. C., and Karig, D. E., 1976. Sedimentology, structural geology, and tectonics of the Shikoku subduction zone, southwestern Japan. Geol. Soc. Am. Bull., 87, 1259-1268.

Norris, D. K., and Barron, K., 1968. Structural analysis of features on natural and artificial faults. Geol. Soc. Can. Paper, No. 68-52, pp. 136-167.

Paterson, M. S., 1958. Experimental deformation and faulting in Wombeyan Marble. Geol. Soc. Am. Bull., 69, 465-476.

Proust, F., Tapponnier, P., and Petit, J-P., 1974. Critères de sens de mouvement sur les miroirs de failles en roches non calcaires. Réunion Annuelle des Sciences de la Terre Résumés, No. 2, p. 320.

Riedel, W., 1929. Zur mechanik geologischer Brucherscheinungen. Centralblatt für Mineralogie, Geologie, und Paläontologie, ser. B,pp. 354-368.

Tchalenko, J. S., 1970. Similarities between shear zones of different magnitudes. Geol. Soc. Am. Bull., 81, 1625-1639.

Tjia, H. D., 1972. Fault movement, reoriented stress field, and subsidiary structures. Pacific Geol., 5, 49-70.

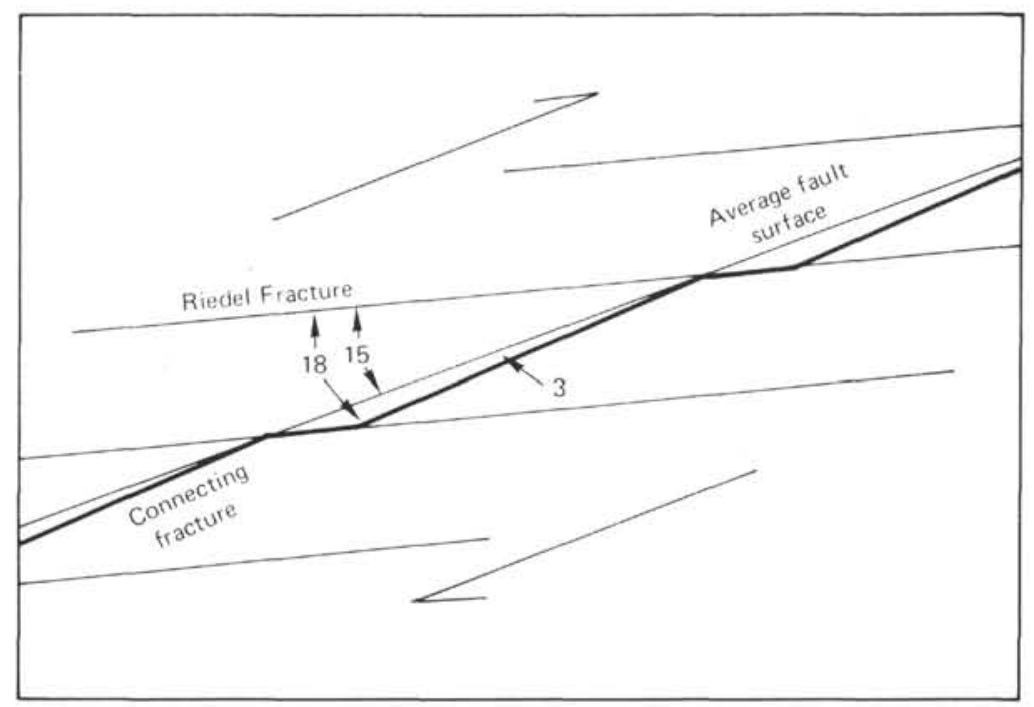

Figure 8. Angular relations between the average shear surface, riedel fractures, and connecting fractures. 


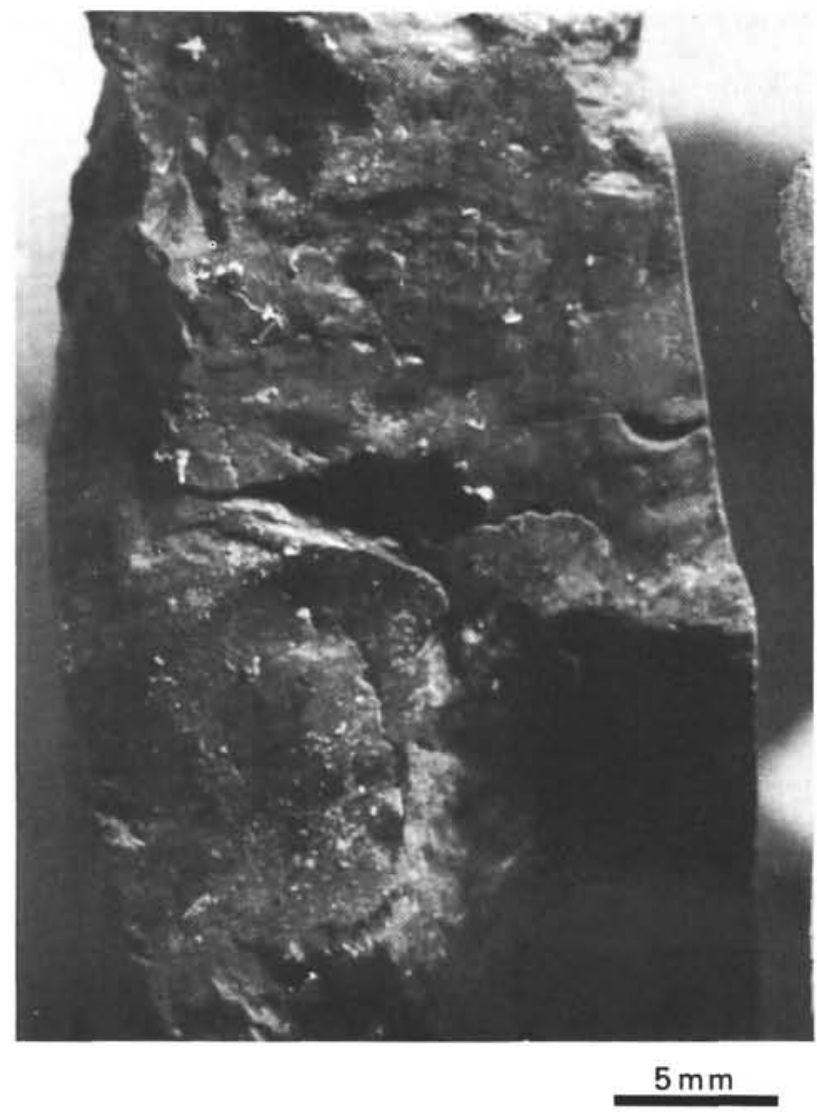

Figure 9. Congruent slickenside steps of Type A indicate that the overlying block moved downward. The missing pieces from the hole-like steps at the center adhered to the overlying block. On these steps the risers are considered incongruent, because they seem to oppose fault movement. The shadowed treads, which are believed to be riedel fractures, lie at about $15^{\circ}$ to the average fault surface. Specimen 441A-11-1, $53 \mathrm{~cm}(586 \mathrm{~m})$, upper Miocene claystone breccia. 


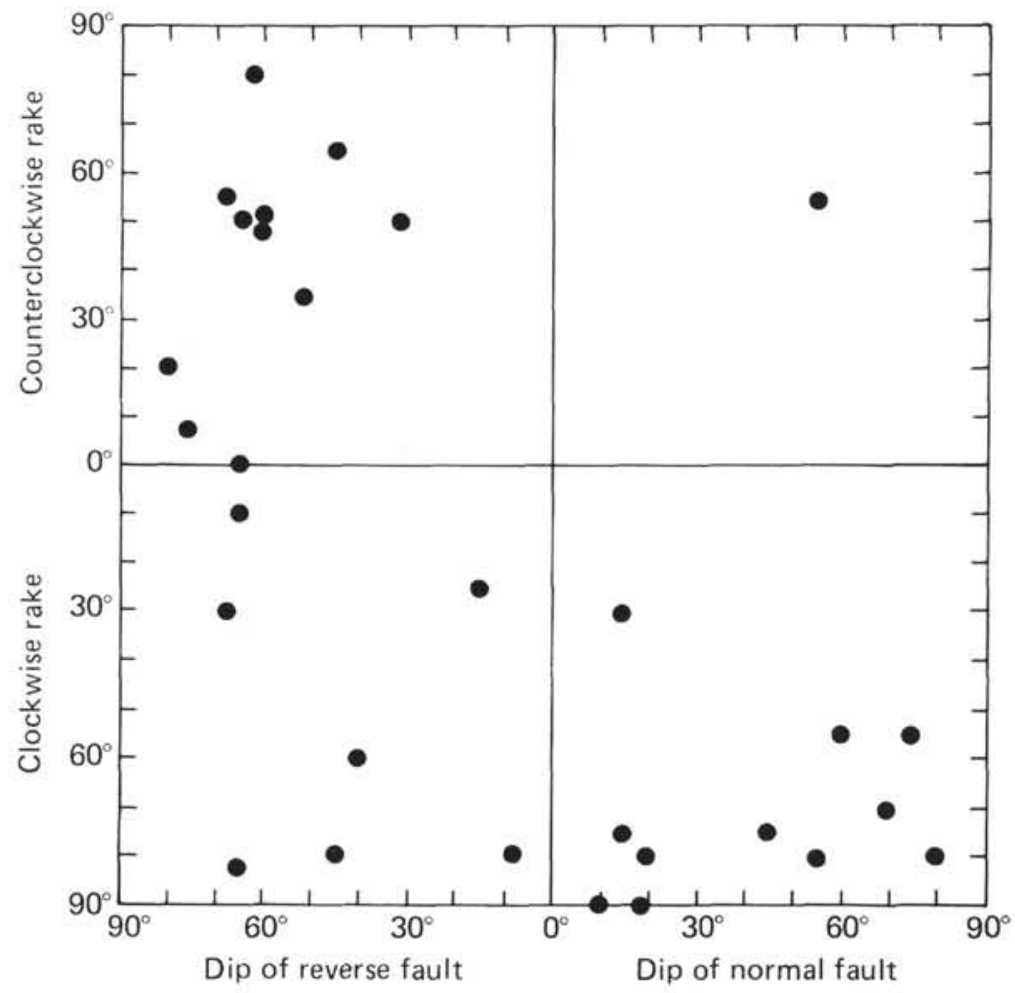

Figure 10. Properties of slickensided faults at Site 441, showing sense of displacement, dip of fault plane, rake of slickensides, and sense of rotation of the rake on the footwall with respect to the horizontal.

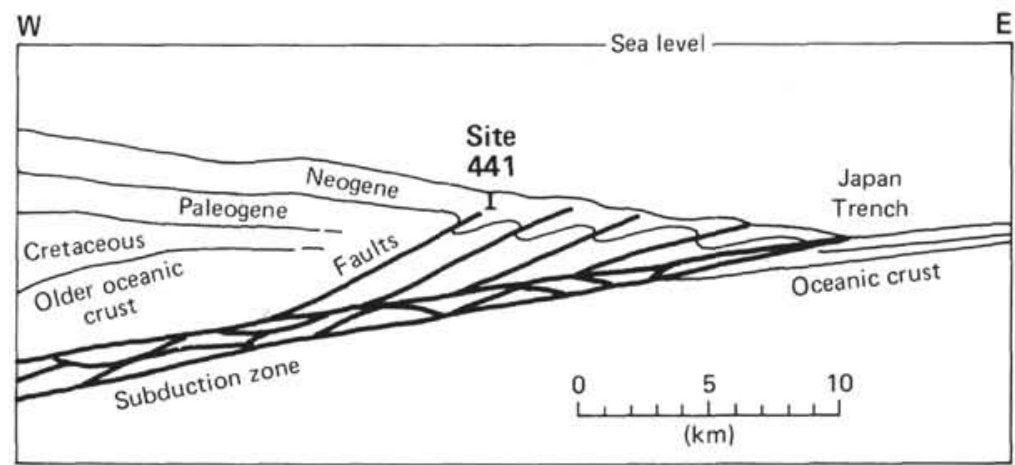

Figure 11. Interpretive true scale diagram of the Japan Trench area showing how shearing might extend into the younger trench slope cover during consolidation and rotation of underlying subductiondisturbed prisms. 
TABLE 1

Properties of Fault-Plane Pairs in Coherent Core Pieces from Site 441

\begin{tabular}{|c|c|c|c|c|c|c|c|}
\hline $\begin{array}{l}\text { Sub-Bottom } \\
\text { Depth }(\mathrm{m})\end{array}$ & $\begin{array}{c}\text { Sample } \\
\text { (Hole 441A; depth in } \mathrm{cm} \text { ) }\end{array}$ & $\begin{array}{c}\text { Dip of } \\
\text { Fault } \\
\left({ }^{\circ}\right)\end{array}$ & $\begin{array}{l}\text { Rake of } \\
\text { Grooves } \\
\left({ }^{\circ}\right)\end{array}$ & $\begin{array}{l}\text { Rotation from } \\
\text { Horizontal }\end{array}$ & $\begin{array}{l}\text { Sense of } \\
\text { Slip }\end{array}$ & $\begin{array}{c}\text { Dihedral } \\
\text { Angle } \\
\left({ }^{\circ}\right)\end{array}$ & $\begin{array}{l}\text { Plunge of } \\
\text { Intersection } \\
\left({ }^{\circ}\right)\end{array}$ \\
\hline $254-326$ & $441 \mathrm{~A}-\mathrm{H} 1-2,70$ & $\begin{array}{l}55 \\
15\end{array}$ & $\begin{array}{l}55 \\
25\end{array}$ & $\begin{array}{l}\text { counterclockwise } \\
\text { clockwise }\end{array}$ & $\begin{array}{l}\text { normal } \\
\text { reverse }\end{array}$ & 101 & +10 \\
\hline $256-328$ & $441 \mathrm{~A}-\mathrm{H} 1-3,115$ & $\begin{array}{l}68 \\
15\end{array}$ & $\begin{array}{l}55 \\
75\end{array}$ & $\begin{array}{l}\text { counterclockwise } \\
\text { clockwise }\end{array}$ & $\begin{array}{l}\text { reverse } \\
\text { normal }\end{array}$ & 89 & -7 \\
\hline $257-329$ & $441 \mathrm{~A}-\mathrm{H} 1-4,17$ & $\begin{array}{l}80 \\
45\end{array}$ & $\begin{array}{l}20 \\
75\end{array}$ & $\begin{array}{l}\text { counterclockwise } \\
\text { clockwise }\end{array}$ & $\begin{array}{l}\text { reverse } \\
\text { normal }\end{array}$ & 58 & -6 \\
\hline 258-329 & $441 \mathrm{~A}-\mathrm{H} 1-4,117$ & $\begin{array}{l}68 \\
15\end{array}$ & $\begin{array}{l}30 \\
30\end{array}$ & $\begin{array}{l}\text { clockwise } \\
\text { clockwise }\end{array}$ & $\begin{array}{l}\text { reverse } \\
\text { normal }\end{array}$ & 80 & +11 \\
\hline $345-398$ & $441 \mathrm{~B}-\mathrm{H} 1-1,90$ & $\begin{array}{r}8 \\
80\end{array}$ & $\begin{array}{l}80 \\
80\end{array}$ & $\begin{array}{l}\text { clockwise } \\
\text { clockwise }\end{array}$ & $\begin{array}{l}\text { reverse } \\
\text { normal }\end{array}$ & 110 & 0 \\
\hline 511 & $441 \mathrm{~A}-8-1,55$ & $\begin{array}{l}65 \\
45\end{array}$ & $\begin{array}{l}10 \\
65\end{array}$ & $\begin{array}{c}\text { clockwise } \\
\text { counterclockwise }\end{array}$ & $\begin{array}{l}\text { reverse } \\
\text { reverse }\end{array}$ & 74 & -10 \\
\hline 586 & $441 \mathrm{~A}-11-1,38$ & $\begin{array}{l}40 \\
70\end{array}$ & $\begin{array}{l}60 \\
70\end{array}$ & $\begin{array}{l}\text { clockwise } \\
\text { clockwise }\end{array}$ & $\begin{array}{l}\text { reverse } \\
\text { normal }\end{array}$ & 93 & +35 \\
\hline 587 & $441 \mathrm{~A}-11-1,53$ & $\begin{array}{l}32 \\
65\end{array}$ & $\begin{array}{l}50 \\
50\end{array}$ & $\begin{array}{l}\text { counterclockwise } \\
\text { counterclockwise }\end{array}$ & $\begin{array}{l}\text { reverse } \\
\text { reverse }\end{array}$ & 155 & -8 \\
\hline
\end{tabular}

Note: The recorded dihedral angle is that which is above both planes; the intersection is positive when it slopes away from the observer in a view in which the steeper plane dips to the right; the depths expressed as intervals indicate the depth ranges for core specimens recovered during wash runs. 